Part of Journal of Research of the National Bureau of Standards, Volume 25, September 1940

\title{
ELECTRODE POTENTIAL MEASUREMENTS AS A MEANS OF STUDYING THE CORROSION CHARACTERISTICS OF WROUGHT ALUMINUM ALLOYS OF THE DURALUMIN TYPE
}

\author{
By Hugh L. Logan
}

ABSTRACT

A study was made of the reliability of basing predictions of the susceptibility of the duralumin-type alloys to intercrystalline corrosion on electrode-potential measurements. These measurements were made in a potassium chloride solution against a saturated calomel electrode.

A condenser, charged by this galvanic cell, was discharged through a calibrated ballistic galvanometer. A comparison of the measured potentials with the result of corrosion tests on the same specimens showed that materials with electrode potentials more negative than -0.657 volt at $25^{\circ} \mathrm{C}$ were in general susceptible to intercrystalline corrosion, and those with less negative potentials were immune to this type of corrosion. Measurements with a potentiometer are less reliable, but may be used to determine whether the potential is above or below -0.657 volt.

\section{CONTENTS}

I. Introduction

II. Materials

III. Determination of electrode potentials

1. Preparation of surface of specimen

2. The calomel electrode

3. Ballistic-galvanometer method

4. Potentiometer method.

IV. Comparison of electrode potentials with results of corrosion tests

1. Susceptibility to intercrystalline corrosion

2. Determination of critical-solution potential

3. Comparison of electrode predictions with metallographic findings 322

V. Summary _. _ _

\section{INTRODUCTION}

The aluminum alloys of the duralumin type attain their high strength and other desirable physical properties by heat-treatment, usually performed in three stages: (a) The alloy is heated at approximately $500^{\circ} \mathrm{C}$ for a sufficiently long period to bring most of the alloying: constituents into a stage of homogeneous solid solution; (b) the material is cooled rapidly to room temperature; and (c) it is aged for several days.

The distinguishing feature of the duralumin alloys is the improvement in the properties of the quenched alloy on aging at room temperature. In some aluminum alloys, "accelerated aging" is necessary, that is, the quenched alloy must be reheated, above room temperature. The designation "duralumin type" is restricted in this report to those heat-treatable aluminum alloys that do not require accelerated aging. 
None of the aluminum alloys are entirely immune to corrosion, although this may be negligible under many conditions of service. The rate of corrosion varies according to the environment, the composition of the alloy, and especially the heat-treatment. The rate at which the material is cooled from the solution-treatment temperature (step b above) is very important in determining the character of any corrosion that may occur. Corrosion of material that has been cooled slowly by quenching in hot water is mostly confined to the grain boundaries and may penetrate rather deeply without leaving any marked evidence of corrosion on the surface. Corrosion of this type may be very damaging to the ductility and strength of the material, especially of sheets.

The same alloy, however, if cooled more rapidly, by quenching in cold water, is practically immune to the intercrystalline type of corrosion, although its initial tensile strength and other properties do not differ essentially from those produced by quenching in hot water. Any corrosion that occurs is generally of the pitting type, which has a much less damaging effect on the tensile strength, ductility, and other physical properties. The damage to the physical properties of duralumin by corrosion varies with the intensity of the intercrystalline attack. Material with only traces of intercrystalline attack may be damaged no more severely than that corroded by pitting.

To illustrate these two types of corrosion, identical specimens from a single sheet were cooled from the solution-heat-treatment temperature by quenching in water at $94^{\circ} \mathrm{C}$ and $26^{\circ} \mathrm{C}$, respectively, and were examined after immersion for equal periods in a corroding solution. The slowly cooled material showed severe attack along the grain boundaries. Its ductility, as measured by the elongation (2-in. gage length) of the specimen broken in tension, was reduced from 21 percent, which was characteristic of the uncorroded condition, to 4.5 percent. Similarly, the ultimate tensile strength was reduced from $66,000 \mathrm{lb} / \mathrm{in}^{2}{ }^{2}$ (in the uncorroded condition) to $40,000 \mathrm{lb} / \mathrm{in}^{2}$ The companion specimen that was cooled rapidly, by quenching in water at room temperature, exhibited only the pitting type of corrosion. The elongation of this specimen after corrosion was 9.4 percent and the ultimate tensile strength was $57,500 \mathrm{lb} / \mathrm{in}^{2}{ }^{2}$

It is evident that a method of testing to indicate the type of corrosive attack that might be expected for any specific lot of a heattreated aluminum alloy would serve a very useful purpose. The method usually employed involves immersion in a sodium chloride solution containing hydrogen peroxide, and examining the microstructure of the corroded material to determine the character of the attack. This method is time-consuming and necessitates the cutting of specimens from the article. A more rapid and nondestructive test has long been sought.

The electrode potential of an alloy of the duralumin type varies with the heat-treatment and particularly with the rate at which the alloy has been cooled after the solution-heat treatment. Attempts ${ }^{12}$ have been made to use this potential to predict the type of corrosion to which the material may be susceptible. This study was conducted to determine the reliability of such predictions.

1 Private Communication from F. P. Somers, Naval Aircraft Factory, Philadelphia, Pa.

Private communication from E. H. Dix, Jr., Aluminum Company of America, New Kensington, P\&. 


\section{MATERIALS}

Alloys of the duralumin type contain as essential alloying constituents, copper, magnesium, manganese, and silicon. Two commercial aluminum alloys, $17 \mathrm{~S}$ and $24 \mathrm{~S}$, with type compositions given in table 1 , were used in this study.

TABLE 1.-Type compositions of commercial alloys of the duralumin type

\begin{tabular}{|c|c|c|}
\hline & $17 \mathrm{~S}$ & $24 \mathrm{~S}$ \\
\hline Copper & \multirow{6}{*}{$\begin{array}{r}\text { Percent } \\
4.0 \\
0.5 \\
0.5 \\
0.1 .0 \\
: 0.8 \\
.0 .38 \\
\text { Remainder }\end{array}$} & \multirow{6}{*}{$\begin{array}{r}\text { Percent } \\
4.4 \\
1.5 \\
0.5 \\
\text { b } 0.5 \\
\text { b } 0.5 \\
\text { b } 0.38 \\
\text { Remainder }\end{array}$} \\
\hline Magnesium.... & & \\
\hline Manganese & & \\
\hline $\begin{array}{l}\text { Iron } \\
\text { Silicon }\end{array}$ & & \\
\hline Other elements, total & & \\
\hline Aluminum............. & & \\
\hline
\end{tabular}

- Maximum permitted in Federal Specification QQ-A-353a.

b Maximum permitted in Federal Specification QQ-A-355.

The material was in sheet form, 0.020 to 0.064 in. thick. Most of the 24S alloy was from 18 lots of commercially heat-treated aluminumalloy sheet. The remainder was commercial sheet heat-treated at the National Bureau of Standards. The 17S alloy included commercial sheets heat-treated at the National Bureau of Standards and commercially heat-treated sheet from two sources. Some heat-treated duralumin of German origin was used for comparison with the 17S material.

\section{DETERMINATION OF ELECTRODE POTENTIALS}

The electrode potential of each metal in a saturated solution of potassium chloride was measured against a saturated calomel electrode. Each reported potential is the emf of a cell in which a small area $(0.8$ to $1 \mathrm{~cm}^{2}$ ) of the metal surface was in contact with the potassium chloride solution that in turn was connected to the calomel electrode. As in all cases the aluminum was negative with respect to the mercury of the half cell, the "electrode potential"' of the aluminum is reported as "negative." An increase in the numerical value of this potential represents a more negative potential and vice versa.

\section{PREPARATION OF SURFACE OF SPECIMEN}

The surface condition of the metal after the heat-treatment varied considerably among specimens from the same lot. In some cases the electrode potential of a specimen was made less negative by the removal of the surface film produced during the heat-treatment. In order to make the potential measurements on all specimens under similar conditions, the surface films were removed with fine emery paper. With careful surface preparation, reproducible results could be obtained for repeated determinations on the same specimen. Vigorous or long-continued abrasion of the surface made the solution potential less negative. Failure to remove all the initial surface film caused a trend in the opposite direction, that is, the measurements were more electronegative than if the surface had been properly prepared. 
In order to obtain reproducible results, no electrode potentials were determined until at least 6 minutes after the surface preparation had been completed. The potentials immediately determined ranged from -0.90 to -1.00 volt. The potential decreased in magnitude with time and approached a constant value in the range -0.628 to -0.755 volt in from 4 to 6 minutes after the surface preparation had been completed.

Although the tensile strength and hardness of these alloys is increased by aging after the heat treatment, the solution potential remained constant.

\section{THE CALOMEL ELECTRODE:}

In order that the test could be applied directly to metal in a finished structure, the calomel electrode of the saturated potassium chloride type shown in figure 1 was constructed. Fresh solution was supplied from the reservoir for each reading. The vent was used to remove air bubbles from the bridge. The contact tip could be used in any position. The rubber gasket served to retain the solution in position, to make the area under test approximately constant, and to prevent scratching the surface film of the alloy while under test. If this surface was scratched, a very high electronegative potential was obtained.

The apparatus and method of making contact through the liquid bridge are shown in figure 2. The electrode was kept at $25^{\circ} \pm 0.1^{\circ} \mathrm{C}$ in a Dewar flask.

The emf of the cell, calomel electrode-aluminum alloy, increased with temperature. For heat-treated $17 \mathrm{~S}$ and $24 \mathrm{~S}$ alloys, the average value of this change from $16^{\circ}$ to $36^{\circ} \mathrm{C}$, with the electrode at $25^{\circ} \mathrm{C}$, was 1.45 millivolts (or for practical purposes, 1.5 millivolts) per degree $\mathbf{C}$.

\section{BALLISTIC-GALVANOMETER METHOD}

The reaction between the potassium chloride solution and the alloy resulted in rapid and unpredictable variations of the potential as measured directly by a potentiometer. This difficulty was overcome by using a condenser and ballistic galvanometer. The galvanic cell containing the aluminum alloy was used to charge a 4-microfarad condenser, and the emf of the cell was then determined by discharging the condenser through a calibrated ballistic galvanometer. This calibration was made by discharging the condenser, after it had been charged to various known potentials, through the galvanometer. Measurements were made with a precision of 1 millivolt. The usual variation of three to five separate potential determinations made on a properly heat-treated specimen of the $24 \mathrm{~S}$ alloy was 5 millivolts, and the averages of successive sets of readings on the same specimen checked to about 3 millivolts. The circuit used for the potential measurements and also the auxiliary circuit for calibrating the galvanometer are shown in figure 3.

\footnotetext{
3 The use of the calomel electrode to predict susceptibility of duralumin to intercrystalline corrosion was called to the author's attention by F. P. Somers of the Naval Aircraft Factory, Philadelphia, Pa. The electrode and the ballistic galvanometer method described in this paper were used to overcome certain difficulties experienced in using the Somers method and electrode.
} 


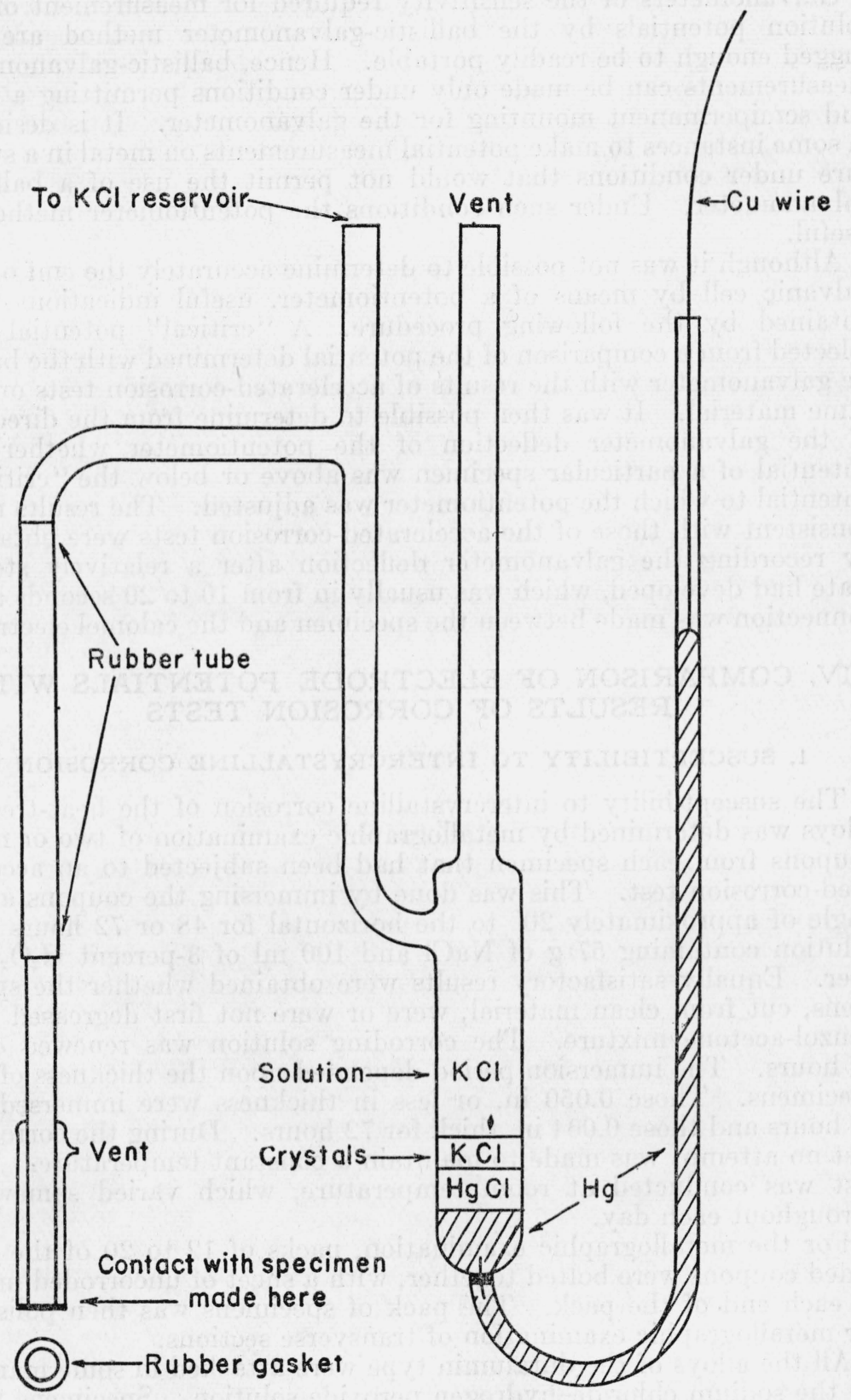

Figure 1.-Schematic diagram of calomel electrode. 


\section{POTENTIOMETER METHOD}

Galvanometers of the sensitivity required for measurement of the solution potentials by the ballistic-galvanometer method are not rugged enough to be readily portable. Hence, ballistic-galvanometer measurements can be made only under conditions permitting a solid and semipermanent mounting for the galvanometer. It is desirable in some instances to make potential measurements on metal in a structure under conditions that would not permit the use of a ballistic galvanometer. Under such conditions the potentiometer method is useful.

Although it was not possible to determine accurately the emf of the galvanic cell by means of a potentiometer, useful indications were obtained by the following procedure. A "critical" potential was selected from a comparison of the potential determined with the ballistic galvanometer with the results of accelerated-corrosion tests on the same material. It was then possible to determine from the direction of the galvanometer deflection of the potentiometer whether the potential of a particular specimen was above or below the "critical" potential to which the potentiometer was adjusted. The results most consistent with those of the accelerated-corrosion tests were obtained by recording the galvanometer deflection after a relatively steady state had developed, which was usually in from 10 to 20 seconds after connection was made between the specimen and the calomel electrode.

\section{COMPARISON OF ELECTRODE POTENTIALS WITH RESULTS OF CORROSION TESTS}

\section{SUSCEPTIBILITY TO INTERCRYSTALLINE CORROSION}

The susceptibility to intercrystalline corrosion of the heat-treated alloys was determined by metallographic examination of two or more coupons from each specimen that had been subjected to an accelerated-corrosion test. This was done by immersing the coupons at an angle of approximately $20^{\circ}$ to the horizontal for 48 or 72 hours in a solution containing $57 \mathrm{~g}$ of $\mathrm{NaCl}$ and $100 \mathrm{ml}$ of 3-percent $\mathrm{H}_{2} \mathrm{O}_{2}$ per liter. Equally satisfactory results were obtained whether the specimens, cut from clean material, were or were not first degreased in a benzol-acetone mixture. The corroding solution was renewed each 24 hours. The immersion period depended upon the thickness of the specimens. Those 0.050 in. or less in thickness were immersed for 48 hours and those 0.064 in. thick for 72 hours. During the corrosion test no attempt was made to maintain a constant temperature. The test was conducted at room temperature, which varied somewhat throughout each day.

For the metallographic examination, packs of 12 to 20 of the corroded coupons were bolted together, with a sheet of uncorroded metal at each end of the pack. The pack of specimens was then polished for metallographic examination of transverse sections.

All the alloys of the duralumin type were attacked in some manner by the sodium chloride-hydrogen peroxide solution. Specimens that had been cooled rapidly from the solution-heat-treatment temperature were subject only to pitting, but those that had been cooled slowly were susceptible to intercrystalline attack.

Specimens found to contain even limited areas of intercrystalline attack of the extent and severity shown in $C$ and $D$, figure 4, and also 


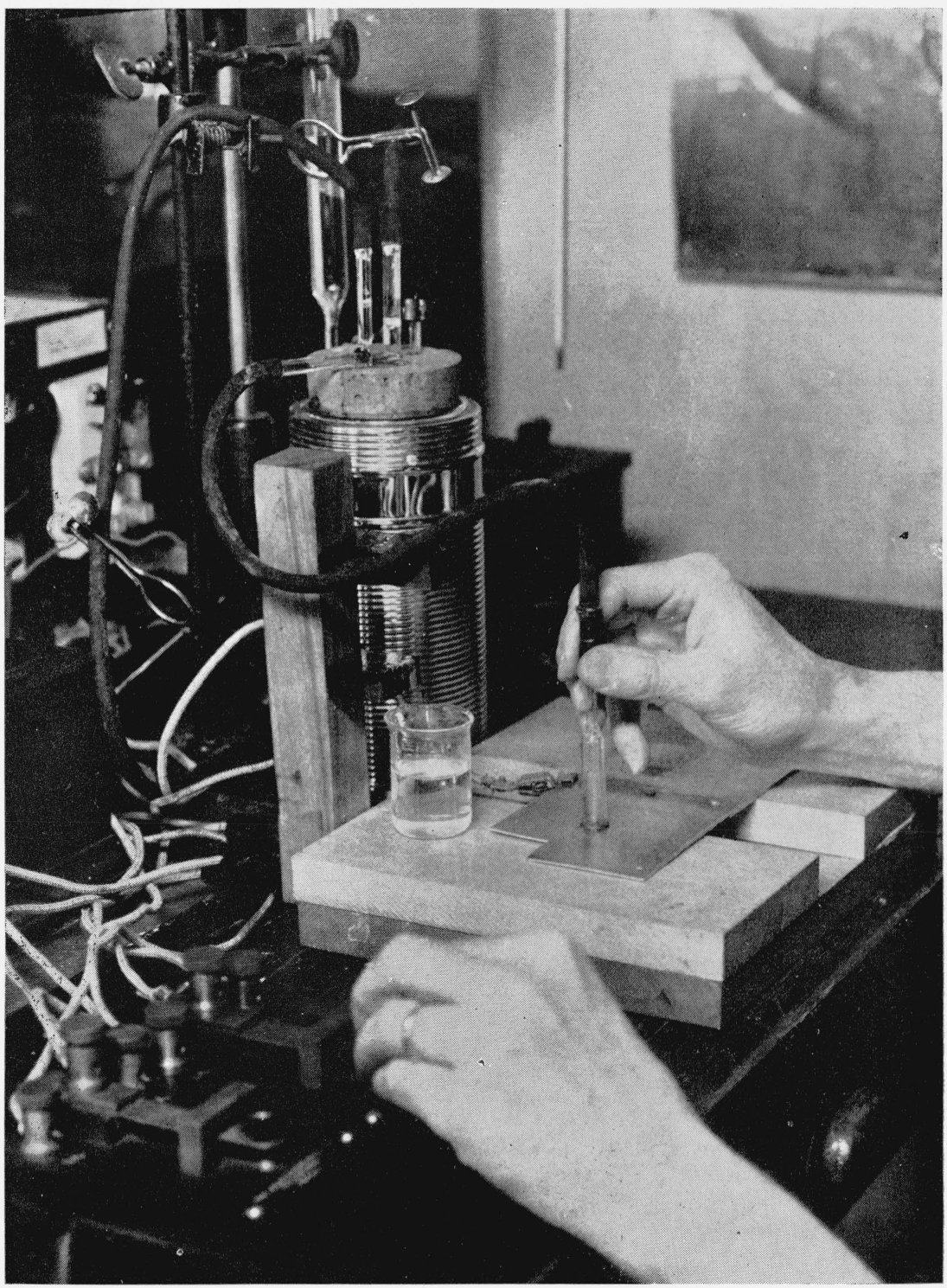

Figure 2.-Calomel electrode in use.

The electrode is contained in the Dewar flask. 

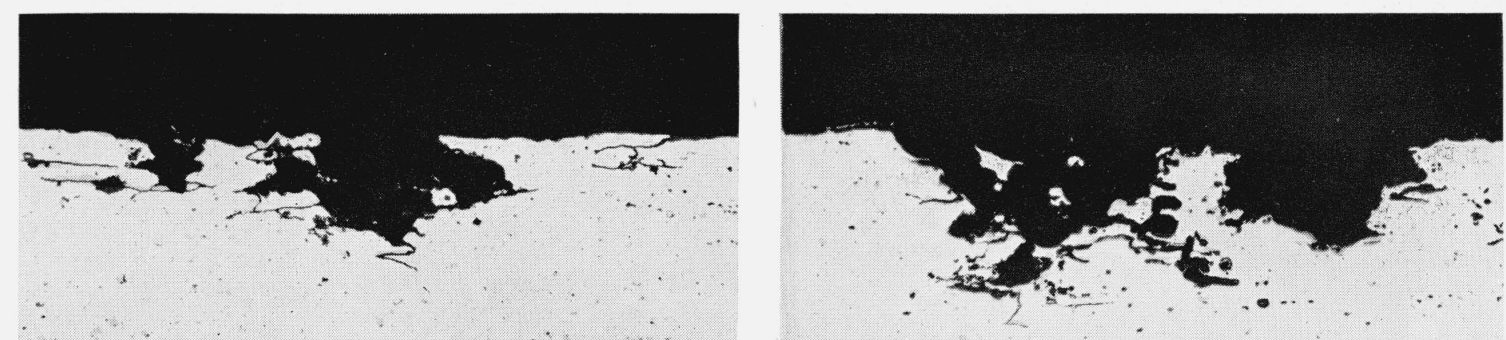

A

B
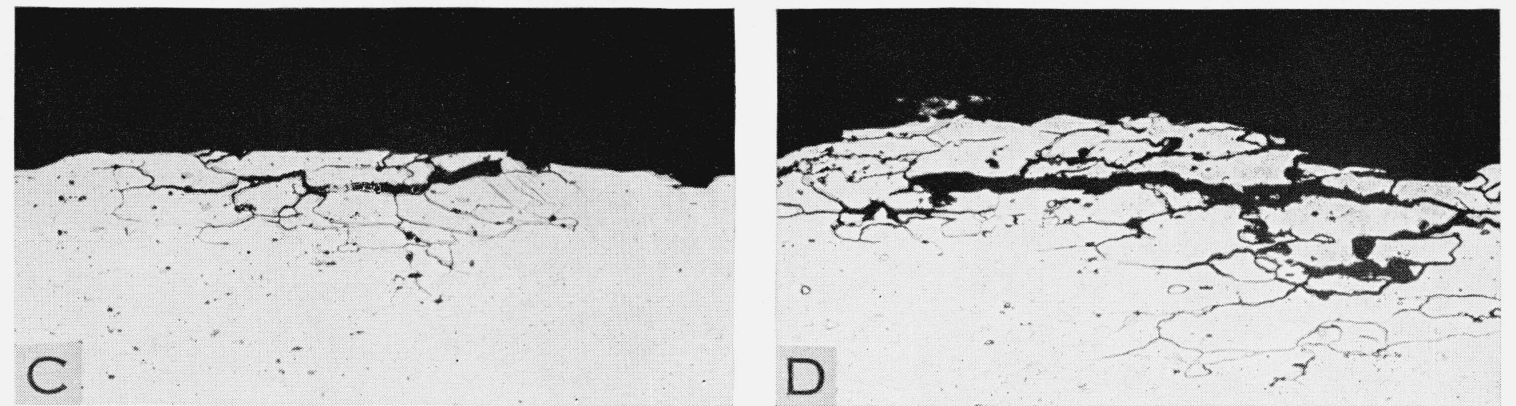

FIGURE 4.-Typical examples of intercrystalline corrosion in $24 S$ alloy.

Photomicrographs show portions of cross-sections of corroded sheet; unetched. $\times 100$

$A$ and $B$, "traces" of intercrystalline corrosion at bottoms of pits. $C$ and $D$, "severe" intercrystalline corrosion. 

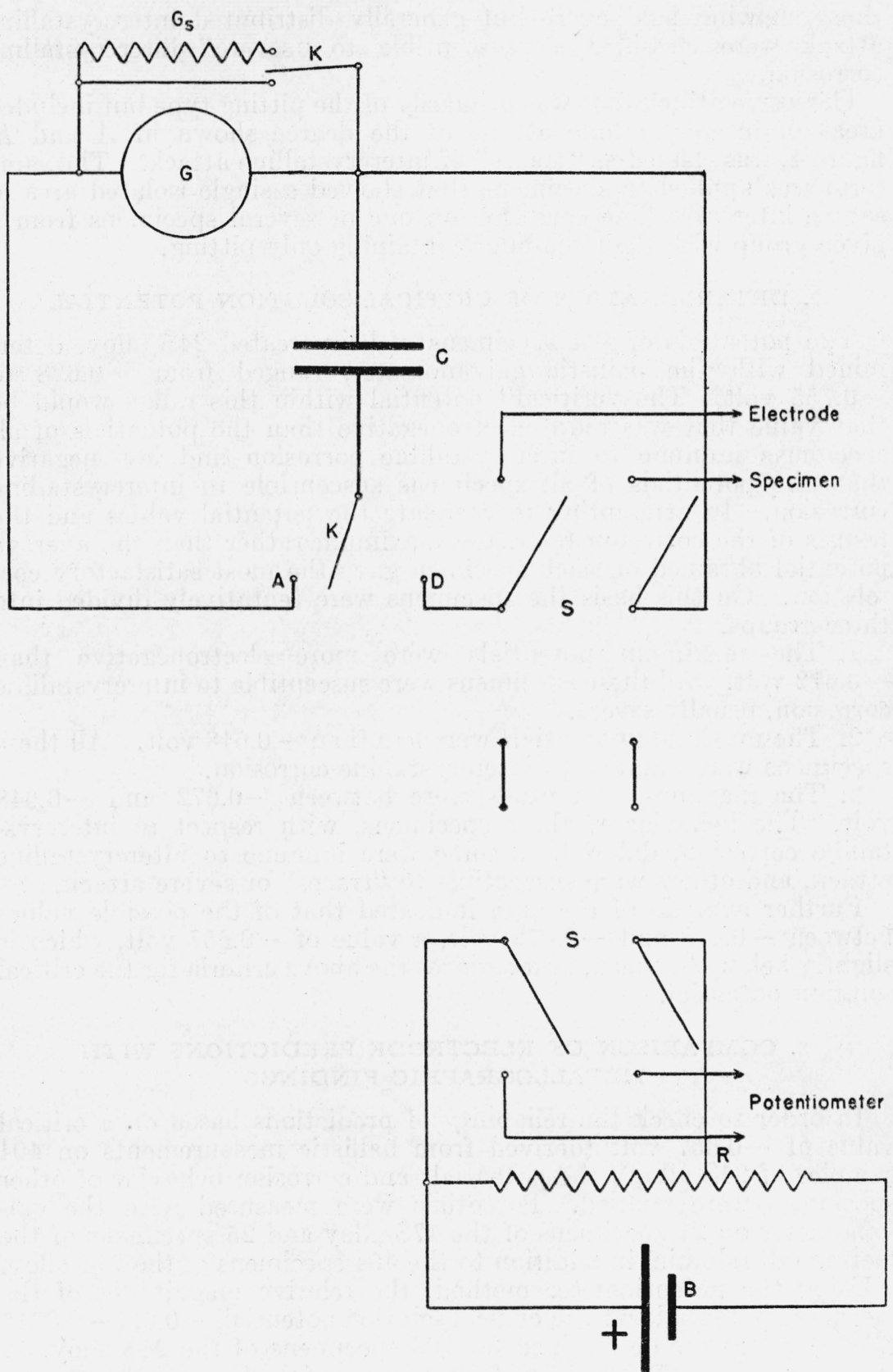

FIGURE 3.-Wiring diagram for potential measurements with ballistic galvanometer.

$B, 1.5$-volt battery; $C$, 4-microfarad condenser; $G$, ballistic galvanometer; $G_{s}$, shunt; $K$, keys; $R, 1500$ ohm radio potentiometer; $S$, switches. 
those showing less severe but generally distributed intercrystalline attack were classified as susceptible to "severe" intercrystalline corrosion.

Corrosive attack that was primarily of the pitting type but included areas of intercrystalline attack of the degree shown in $A$ and $B$, figure 4, was classed as "traces" of intercrystalline attack. The same term was applied to specimens that showed a single isolated area of severe intercrystalline corrosion on one of several specimens from a given group with the remainder containing only pitting.

\section{DETERMINATION OF CRITICAL-SOLUTION POTENTIAL}

The potentials of 404 specimens of heat-treated $24 \mathrm{~S}$ alloy, determined with the ballistic galvanometer, ranged from -0.628 to -0.755 volt. The "critical" potential within this range would be that value that was more electronegative than the potentials of all specimens immune to intercrystalline corrosion and less negative than the potentials of all specimens susceptible to intercrystalline corrosion. In attempting to correlate the potential values and the results of the corrosion tests, the maximum rather than the average potential obtained on each specimen gave the most satisfactory correlation. On this basis the specimens were tentatively divided into three groups:

1. The maximum potentials were more electronegative than -0.672 volt. All these specimens were susceptible to intercrystalline corrosion, usually severe.

2. The maximum potentials were less than -0.648 volt. All these specimens were immune to intercrystalline corrosion.

3. The maximum potentials were between -0.672 and -0.648 volt. The behavior of these specimens, with respect to intercrystalline corrosion, differed, as some were immune to intercrystalline attack, and others were susceptible to "traces" or severe attack.

Further analysis of the data indicated that of the possible values between -0.648 and -0.672 volt, a value of -0.657 volt, which is slightly below the mean, best satisfies the above criteria for the critical solution potential.

\section{COMPARISON OF ELECTRODE PREDICTIONS WITH METALLOGRAPHIC FINDINGS}

In order to check the reliability of predictions based on a critical value of -0.657 volt (derived from ballistic measurements on 404 samples of $24 \mathrm{~S}$ alloy), the potentials and corrosion behavior of other specimens were studied. Potentials were measured with the galvanometer on 21 specimens of the $17 \mathrm{~S}$ alloy and 25 specimens of the German duralumin, in addition to the 404 specimens of the $24 \mathrm{~S}$ alloy.

Using the potentiometer method, the relative magnitudes of the measured potential and the critical solution potential, $-0.657-0.0015$ (T-25) volt, were determined for 200 specimens of the $24 \mathrm{~S}$ alloy, 42 specimens of the $17 \mathrm{~S}$ alloy, and 25 specimens of the German duralumin.

Measurements of the potential of each specimen were made at three to five locations on surfaces prepared as described in section III. If any potential measurement was more negative than -0.657 volt (when corrected to $25^{\circ} \mathrm{C}$ ), the surface preparation was repeated and an additional set of readings was made. If, in the second set of readings, any value was greater than -0.657 volt, the specimen was 
classified as susceptible to intercrystalline corrosion in some degree. Some materials that were susceptible only to traces of intercrystalline corrosion had potentials as negative as -0.690 volt, which shows that it is not possible to predict the degree of intercrystalline corrosion from potential measurements.

A comparison of the predictions of susceptibility to intercrystalline corrosion with the microscopic examinations of corroded coupons of the same specimen is given in table 2:

TABLE 2.-Comparison of the predictions of susceptibility to intercrystalline corrosion from potential measurements and the results of the accelerated corrosion tests

\begin{tabular}{|c|c|c|c|c|c|c|c|}
\hline \multirow[b]{2}{*}{ Material } & \multirow{2}{*}{$\begin{array}{l}\text { Method of determining } \\
\text { potential }\end{array}$} & \multirow{2}{*}{$\begin{array}{l}\text { Num- } \\
\text { ber of } \\
\text { speci- } \\
\text { mens } \\
\text { exam- } \\
\text { ined }\end{array}$} & \multicolumn{2}{|c|}{$\begin{array}{l}\text { Predictions based } \\
\text { on potential } \\
\text { measurement }\end{array}$} & \multicolumn{2}{|c|}{$\begin{array}{l}\text { Predictions con- } \\
\text { firmed by micro- } \\
\text { scopic examina- } \\
\text { tion of corroded } \\
\text { specimens }\end{array}$} & \multirow{2}{*}{$\begin{array}{l}\text { Per- } \\
\text { centage } \\
\text { of cor- } \\
\text { rect pre- } \\
\text { dictions }\end{array}$} \\
\hline & & & $\begin{array}{c}\text { Speci- } \\
\text { mens sus- } \\
\text { ceptibleto } \\
\text { intercrys- } \\
\text { talline } \\
\text { corrosion }\end{array}$ & $\begin{array}{c}\text { Speci- } \\
\text { mens im- } \\
\text { mune to } \\
\text { in tercrys- } \\
\text { talline } \\
\text { corrosion }\end{array}$ & $\begin{array}{c}\text { Speci- } \\
\text { mens sus- } \\
\text { ceptibleto } \\
\text { intercry s- } \\
\text { talline } \\
\text { corrosion }\end{array}$ & $\begin{array}{c}\text { Speci- } \\
\text { mens im- } \\
\text { mune to } \\
\text { intercry s- } \\
\text { talline } \\
\text { corrosion }\end{array}$ & \\
\hline $24 \mathrm{~S}$ & alvanomet & 40 & 154 & 250 & 126 & 227 & \\
\hline${ }_{17 S}$ Do.. & Potentiometer & 200 & 46 & 154 & 39 & 132 & 85 \\
\hline $17 \mathrm{~S}_{\mathrm{D}}$ & Ballistic galvanom & 21 & 13 & 8 & 12 & 7 & 90 \\
\hline Do. & Potentiometer & 42 & 17 & 25 & 12 & 23 & 86 \\
\hline German duralumin & Ballistic galvano & 25 & 23 & 2 & 21 & 1 & 88 \\
\hline Do & Potentiometer & 25 & 19 & & 19 & 3 & 88 \\
\hline
\end{tabular}

The percentages of correct predictions in table 2 refer to all degrees of intercrystalline corrosion. As stated, it is not generally possible to predict the degree of intercrystalline attack from potential measurements. The data initable 3 show that potential measurements with the ballistic method yielded correct predictions for nearly all the specimens that showed severe intercrystalline corrosion and for a large proportion of those that showed traces of corrosion. For the latter class, the potentiometer measurements are less reliable.

TABLE 3.-Proportion of specimens found to be susceptible to severe or traces of intercrystalline attack in the corrosion test that was predicted from potential measurements to be susceptible to intercrystalline attack

\begin{tabular}{|c|c|c|c|c|c|c|c|c|}
\hline \multirow[t]{3}{*}{ Material } & \multirow{3}{*}{$\begin{array}{l}\text { Method of determining } \\
\text { solution potential }\end{array}$} & \multirow{3}{*}{$\begin{array}{l}\text { Num- } \\
\text { ber of } \\
\text { speci- } \\
\text { mens } \\
\text { exam- } \\
\text { ined }\end{array}$} & \multicolumn{2}{|c|}{$\begin{array}{l}\text { Rating of ma- } \\
\text { terial on basis } \\
\text { of results of } \\
\text { corrosion tests. } \\
\text { Number of } \\
\text { specimens sus- } \\
\text { ceptible to in- } \\
\text { tercrystalline } \\
\text { corrosion }\end{array}$} & \multicolumn{4}{|c|}{$\begin{array}{l}\text { Specimens predicted to be sus } \\
\text { ceptible to intercrystalline cor } \\
\text { rosion in some degree that were } \\
\text { subject to }\end{array}$} \\
\hline & & & \multirow[b]{2}{*}{$\begin{array}{l}\text { Severe } \\
\text { attack }\end{array}$} & \multirow[b]{2}{*}{$\begin{array}{l}\text { Traces } \\
\text { of at- } \\
\text { tack }\end{array}$} & \multicolumn{2}{|c|}{ Severe attack } & \multicolumn{2}{|c|}{ Traces of attack } \\
\hline & & & & & $\begin{array}{l}\text { Num- } \\
\text { ber of } \\
\text { speci- } \\
\text { mens }\end{array}$ & $\begin{array}{l}\text { Per- } \\
\text { cent }\end{array}$ & $\begin{array}{l}\text { Num- } \\
\text { ber of } \\
\text { speci- } \\
\text { mens }\end{array}$ & $\begin{array}{l}\text { Per- } \\
\text { cent }\end{array}$ \\
\hline $24 \mathrm{~S}$ & Ballistic galvanometer. & 404 & 74 & & 73 & & 53 & \\
\hline Do. & Potentiometer & 200 & 33 & 28 & 30 & 90.9 & 9 & 32.1 \\
\hline $17 \mathrm{~S} \ldots$ & Ballistic galvanometer. & 21 & 9 & 4 & 9 & 100 & 3 & 75 \\
\hline Do. & Potentiometer......... & 42 & 11 & 3 & 11 & 100 & 1 & 33.3 \\
\hline German duralumin. & Ballistic galvanometer. & 25 & 10 & 12 & 9 & 90 & 12 & 100 \\
\hline Do.......... & Potentiometer. & 25 & 10 & 12 & 8 & 80 & 11 & 91.7 \\
\hline
\end{tabular}


Although it may be desirable that any method of separating specimens of aluminum alloys, on the basis of resistance to corrosive attack, should correctly indicate all materials that are at all susceptible to intercrystalline attack, it is more important that the predictions be correct for those samples that are susceptible to severe intercrystalline attack.

Where a readily portable instrument is required, valuable indications of the susceptibility of material to intercrystalline corrosion can be obtained by means of the potentiometer, but the ballistic-galvanometer method should be used if feasible.

The lack of complete agreement between the predictions and the results of the corrosion tests can be attributed in part to:

Nonuniform heat-treatment of specimens.-On certain specimens, some areas were susceptible to intercrystalline attack while others were not. Complete agreement between the potential measurements and the results of the corrosion test can be expected only if potential measurements were made upon the areas chosen for microscopic examination after immersion in the corroding solution. Usually, the potential measurements and corrosion tests were made upon different parts of the specimen.

Some specimens heat-treated at temperatures below the recommended range, or heat-treated for a very short time in the recommended range, had more negative potentials than -0.657 volt, although the specimens were immune to intercrystalline attack.

Improper surface preparation.-In some cases, failure to remove all the surface films that had been produced during heat-treatment resulted in potentials more negative than the critical potential, although the material when corroded showed only pitting. Conversely, too vigorous abrasion of the surface to remove the film lowered the potentials of certain specimens, known to be susceptible to intercrystalline corrosion, to a value below the critical potential.

Experiments on materials of known composition indicated that differences in copper content are not an appreciable source of error in this work.

Potential measurements as a means of predicting susceptibility of aluminum alloys to intercrystalline corrosion, made by persons with training and experience in physical chemistry, furnish a rapid, reliable method of checking heat-treatment. It is possible by this method, without destroying the structure, to predict with a high degree of certainty whether material in a structure such as an airplane wing is susceptible to intercrystalline corrosion. On the other hand, predictions based on potential measurements do not, in general, indicate the degree of susceptibility to intercrystalline attack. In its present state of development, this method is not one to be entrusted to inspectors who lack broad training in science. It is therefore recommended that this method be used to supplement rather than to replace the present accelerated-corrosion tests.

\section{SUMMARY}

1. The reliability of predictions of susceptibility of duralumin-type alloys to intercrystalline corrosion from measurements of electrochemical potentials was investigated. 
2. The potential determinations are most accurately made by charging a condenser, by means of a galvanic cell consisting of a calomel electrode and the alloy, and discharging the condenser through a calibrated ballistic galvanometer.

3 . The relative potential of a material can be determined by setting a potentiometer to a predetermined potential and determining from the galvanometer deflection whether the potential is greater or less than the chosen value.

4. The predicted susceptibilities to intercrystalline corrosion were compared with the results of accelerated-corrosion tests, carried out by immersing specimens for 48 to 72 hours in a solution of sodium chloride and hydrogen peroxide.

5. A potential of $-0.657-0.0015\left(\mathrm{~T}-25^{\circ} \mathrm{C}\right)$ volt was selected as the critical solution potential. Intercrystalline corrosion in some degree was correctly predicted from ballistic galvanometer measurements in 98.6 percent of the 24ST specimens that were rated by corrosion tests as subject to severe intercrystalline corrosion. Susceptibility or immunity to intercrystalline attack was correctly predicted in 87 percent of all specimens.

6. Intercrystalline corrosion in some degree was correctly predicted from potential measurements with the potentiometer method on 91 percent of 24ST specimens that were susceptible to severe intercrystalline corrosion. Correct predictions of susceptibility or immunity of material to intercrystalline corrosion were made on 85.5 percent of all the specimens.

7. There was insufficient material available to determine whether 0.657 volt is a satisfactory critical potential for $17 \mathrm{~S}$ and German duralumin.

8. It is recommended that the potential method of predicting susceptibility to intercrystalline corrosion be used by scientifically trained personnel to supplement rather than to replace the present accelerated corrosion test.

Washington, June 1, 1940. 